\title{
The Influence of Transformational Leadership on Perceived Ethical Leadership
}

\author{
Mohd Nizam Mohd Ali, Siti Aisyah Panatik, Mohammad Saipol Mohd Sukor, Azizah Rajab
}

\begin{abstract}
The present study aims to examine the influence of transformational leadership on perceived ethical leadership among police officers at the Royal Malaysia Police. Seven dimensions of transformational leadership have been utilised as the predictors of perceived ethical leadership. The target population for the present study are the officers and other ranks staff at the Royal Malaysian Police. The data for this study is collected through survey by using questionnaire. The structural equation modeling using AMOS version 21 was carried out to analyse the data. The findings of this study indicated inspirational motivation, fostering acceptance of group goals and high performance expectations were significantly predicted the level of perceived ethical leadership among respondents.
\end{abstract}

Keywords: Transformational Leadership, Ethical Leadership, Police

\section{INTRODUCTION}

According to the 2013 Global Corruption Barometer ${ }^{26}$, police has been perceived as the second institution to be the most affected by corruption after political parties from a global survey in 2013. Alarmingly within Malaysia's respondents' data set, $76 \%$ of respondents felt that police was the most corrupt institution that has put Malaysia into a group of 36 countries where police were identified as the institution most affected by corruption ${ }^{26}$. Nonetheless, the 'bad apple' theory of police corruption has been recognised as inadequate. What has begun to replace that theory is recognition that enhancing police integrity is an organisational and administrative responsibility that goes well beyond the culling out of 'bad apple' police officers ${ }^{18}$.

The corruption-centric focus on the police within Malaysia does not necessarily capture the whole realities of the institutional profile. 98 public complaints (out of 926 complaints) were received on police corruption and an internal survey among police personnel found that the corruption awareness is significantly low among the personnel at all levels ${ }^{23}$. It was also reported that $61 \%$ of the public respondents who made calls to report a crime, an accident or other reasons were not satisfied with the police response time to arrive at the scene. $32.2 \%$ of the respondents said the police were not concerned with their problems while $15.3 \%$ said that they displayed low integrity. $45.3 \%$ of the respondents did not want to make police reports even as a crime victim due to reasons that either the police was unable to do anything or would not assist whereas $41 \%$ cited similar reasons as a witness to a crime. $28.1 \%$ of the respondents said

Revised Manuscript Received on October15, 2019.

Mohd. Nizam Mohd. Ali, Institut Integriti Malaysia, Kuala Lumpur.

Siti Aisyah Panatik, School of HRD and Psychology, UTM, Malaysia.

Mohammad Saipol Mohd. Sukor, School of HRD and Psychology, UTM, Malaysia.

Azizah Rajab, Language Academy, UTM, Malaysia. that they gave bribes exactly because police requested them when caught exceeding the speed limit.

Based on the report of ${ }^{29}$ indicated that a total of 2087 police personnel consist of 806 officers and 1281 other ranks staff was selected to gauge their own responses towards integrity, work ethics, job importance and job satisfaction. $26 \%$ of the respondents - who were officers - did not think that accepting free drinks or meals from shops while patrolling was a violation of the official police policy, $17 \%$ said the same on accepting gifts or hampers from traders during festive occasions, $12 \%$ on carrying out business after office hours, $9.6 \%$ on cover-up for own police officer for driving under the influence of alcohol in early morning and $9 \%$ on getting time-off in lieu of time taken during public holidays for fixing superior officer's car. In contrast, 26\% of the respondents - who were other ranks - did not think that accepting free drinks or meals from shops while patrolling was a violation of the official police policy. $23 \%$ said the same on carrying out business, $21 \%$ on accepting gifts or hampers, $8 \%$ on covering up others and $12 \%$ on getting time-off.

Thus, this study focuses on issues of leadership and police ethical behaviour. As argued by ${ }^{21}$, leadership is consistently identified as one of the most important aspects to maintaining police ethical behaviour. The research literature on ethical leadership identifies how principles - such as social learning theory, transformational and transactional leadership can effectively promote ethical behaviour. Through adopting particular leadership styles, leaders can promote and inspire value systems, set standards, reinforce performance, respond to problems, and transform organisations from a collection of individuals to a collective with shared principles ${ }^{22}$.

Leadership in the police force plays a critical role in managing the expectations from the society. Police are required to understand and effectively operate in a complex social, political, and organisational environment ${ }^{12}$. Good leadership is fundamental to high performance in such realms and as such, the need for good police leadership is greater now than ever ${ }^{19}$. Malaysia has been blessed with many top police leaders since its independence in 1957. These police leaders were mainly Malaysian, with the exception of the first one, being a British police officer during the transition years from 1958 to 1962. Yet, studies on their leadership styles and values that define them are still limited in Malaysia compared to other organisations in the Malaysian civil service.

In order to build a conceptual model that suits the context of the research, it is important for the researcher to find empirical evidence regarding the study of police leadership particularly within the Malaysian context. 


\section{The Influence of Transformational Leadership on Perceived Ethical Leadership}

It was found from the literature that there were some theoretical and empirical evidences on leadership among employees including police, soldier, and other paramilitary personnel in the Western countries. Majority of the literature on police institution were from the United States of America, United Kingdom, Australia, Canada and New Zealand ${ }^{20}$. However there is little evidence to be found in the Malaysian context especially one that addresses and investigates the transformational leadership style, perceived ethical leadership within the Royal Malaysian Police (RMP). Hence, it is deemed to be important to study the leadership styles of the Malaysian police leaders and officers, especially on their transformational leadership style and perceived ethical leadership such that the outcome could be compared with other findings from the literature. This study is proposed to solely address the influence of the transformational leadership style on perceived ethical leadership among Malaysian police officers and personnel. This study shall underpin the literature as well as reducing the research gap by providing essential information regarding the Malaysian police leadership i.e., transformational leadership style and perceived ethical leadership.

\section{LITERATURE REVIEW}

\section{A. Transformational Leadership and Perceived Ethical Leadership}

There have been an increasing interest in the subject of leadership and ethics over the last decade ${ }^{1,7,25}$. Yet, regardless of the supposed significance of ethics and integrity in an effective leadership, studies on them are still limited ${ }^{24,27}$. Perceived transformation leaders defined by ${ }^{8}$ as "one that was necessarily elevating, putting his emphasis on whether society ultimately benefits from them". On the other hand, ${ }^{3}$ claimed that the transformational leadership is not certainly advantageous leadership, indeed actions could be costly to all concerned rather than beneficial. However, they contradicted each other when Bass considered Hitler to be a transformational leader that Burns disagreed with.

Nonetheless, in Bass subsequent works ${ }^{5}$, he distinguishes between the 'truly' transformational leaders (share a genuine interest in others' welfare) with 'pseudo' transformational leaders (focusing on the benefits that they get). Therefore, true transformational leadership would customarily stimulate followers to willingly recognize and voluntarily fulfil the organisation purposes and they generally do it for the unpretentious dedications. ${ }^{20}$ stated that the type of leadership style transforms followers into leaders who will take charge of their own ethical behaviour. As a result, transformational leadership style is connected with the post-conventional phases of moral expansion, which practice general ethical principles to elucidate dilemmas serving the common good $^{16}$.

The mutually dependent and culturally diverse organisations require transformational leaders to carry out the followers' creativity, imagination, and best efforts ${ }^{11}$. When leaders are more capable, those they lead will be more effective; correspondingly, when leaders are ethically mature, those they lead would display higher moral reasoning ${ }^{15}$. Transformational leaders would also concentrate on terminal values such as integrity and fairness ${ }^{6}$. Based from the study $\mathrm{by}^{7}$, they found that ethical leadership was associated to consideration behaviour, trustworthiness, faith in the leader, interactional equality and mingled charismatic leadership (as measured by the idealised influence dimension of the transformational leadership style). They also established that the ethical leadership foresees outcomes such as perceived efficacy of leaders, followers' job fulfilment and devotion, and their readiness to report difficulties to the upper management.

Another study by ${ }^{1}$ among 102 managers from a large national bank in India focusing on seeing the effects of leader femininity and masculinity on transformational leadership style and the relationship between all the three constructs with the leader ethical behaviour. Despite debates on the ethical behaviours with the transformational leaders in the past, this study had shown a positive relationship between these two variables. Transformational leaders have higher level of integrity and they form trust in themselves by virtue of their being perceived by their followers as being charismatic.

${ }^{25}$ study also sets out to analyse the relationship between the dimensions of transformational leadership style and ethics among 378 managerial level employees in different business organisations in and around Delhi in India. The results show that the transformational leadership style and its dimensions of articulate vision, individualised support, appropriate role model, and foster acceptance of goals were significantly related to ethics at workplace. She concluded that managers in organisation have to acquire the abilities and aptitude to develop articulating vision for the employees of their organisation in addition to providing them with necessary support whenever required. They have to act as a role model and practice ethical and moral values as employees look up to their leaders and follow their behaviours to promote ethical behaviour at the workplace. Leaders should be able to set high moral and ethical goals for their subordinates and foster acceptance to these goals if they want to create and maintain ethical behaviours at the workplace.

Therefore, based on analysis from previous studies, the researcher would likely to conclude that there are relationships between transformational leadership style and perceived ethical leadership. This study tests the following hypothesis:

Hypothesis 1: Transformational leadership positively affects perceived ethical leadership

H1a: Inspirational motivation positively affects perceived ethical leadership

H1b: Appropriate role model positively affects perceived ethical leadership

H1c: Fostering acceptance of group goals positively affects perceived ethical leadership

H1d: High performance expectations positively affect perceived ethical leadership

H1e: Intellectual stimulation positively affects perceived ethical leadership

H1f: Individual consideration positively affects perceived ethical leadership

$\mathrm{H} 1 \mathrm{~g}$ : Contingent reward positively affects perceived ethical leadership 


\section{B. Conceptual Framework}

\section{Transformational leadership}

1. Inspirational motivation

2. Appropriate role model

3. Fostering acceptance of group goals

4. High performance

expectations

5. Intellectual stimulation

6. Individual consideration

7. Contingent reward

Figure 1: Conceptual framework of the study

Figure 1 depicts the conceptual framework of this research. The first part of the framework portraying transformational leadership and its seven dimensions (i.e., inspirational motivation, appropriate role model, fostering acceptance of group goals, high performance expectations, intellectual stimulation, individual consideration, and contingent reward which represent the predictor of the research. The second part of the framework depicts perceived ethical leadership the outcomes of the research. The framework suggests that when police personnel perceive a state of transformational leadership in their leader, this will influence their perception towards their leader's ethical leadership.

The relationship between the transformational leadership style and perceived ethical leadership could be theoretically linked to the social learning theory. The social learning theory posits that learning is a cognitive process that takes place in a social context and proposed that learning can occur simply by observing the actions of others ${ }^{2}$. If police leaders were being perceived as a transformational leader by their followers, they would then perceive their leaders as an ethical leader too. The social learning theory suggests that for a leader to be seen as an ethical leader, he or she must be an attractive and a credible role model ${ }^{6}$, which is consistent with the dimension of the transformational leadership style. It is theorised that a positive transformational leadership style will affect the followers' positive perception towards their leader's ethical leadership.

\section{METHODOLOGY}

\section{A. Population and Sample}

The population of this study was the Royal Malaysian Police. The sample was selected by using convenience sampling method. A total of 396 respondents participated in this study. Majority of the respondents were male, which is 95.5\% respondents were male and only $4.5 \%$ were females. Majority of the respondents were Malay that is $90.2 \%$. Chinese and Indians respondents were in the same ratio that is $3.8 \%$ each race. Only $2.3 \%$ of respondents belonged to other diverse races. In terms of age, majority of the respondents can be considered senior citizens as $54.8 \%$ respondents were around 45 to 54 years old and around $20.5 \%$ respondents were above 55 years age. $15.7 \%$ of respondents were falling between range of 35 to 44 and only small percentage of respondents was below 35 years i.e. 9.1\%. Most of them were married i.e. 95.5\%. Only seven respondents were single and 10 were divorced or widowed. $64.4 \%$ of respondents had secondary education (PMR or SPM) only. $19.2 \%$ had certification or diploma. Small percentage had degree or advanced degree qualification i.e. $18 \%$ approximately. Rank of the respondents in the current organization was also recorded. 247 respondents that are $62.4 \%$ were junior employees in organization. $28 \%$ respondents were senior employees in organization. Only $7.6 \%$ respondents had managerial position while $2 \%$ were at employees' position. Information about total work experience of the respondents was also collected. $63.9 \%$ of the respondents had work experience above 25 years. $13.1 \%$ respondents had work experience ranging from 21 to 25 years. $8.1 \%$ respondents had work experience of 16 to 20 years. $7.8 \%$ respondents had experience of 11 to 15 years. $4.3 \%$ respondents work experience was ranging from 5 to 10 years. Only $2.6 \%$ respondents had work experience of below five years.

\section{B. Measures}

Transformational leadership was measured using the adapted version of the Differentiated Transformational Leadership Inventory (DTLI) ${ }^{9}$. The adapted DTLI contains 27 items that consisted of seven subscales, namely individual consideration, inspirational motivation, intellectual stimulation, fostering acceptance of group goals and promoting team work, high performance expectations, appropriate role model, and contingency reward. Each item is rated on a 5-point Likert scale ranging from 1 (not at all) to 5 (all of the time). The DTLI shows a good model fit when incorporating all seven subscales $(\chi 2=499.1, \chi 2 / \mathrm{df}=1.80$, RMSEA $=0.05$, SRMR $=0.06, \mathrm{NNFI}=0.98, \mathrm{CFI}=0.98)$.

Perceived ethical leadership was measured using Perceived Leader Integrity Scale (PLIS) developed by ${ }^{14}$. This scale consisted of 32 items containing behavioural statements that describe generally accepted ethical or unethical behaviours that can be observed by a subordinate. These items are weighted in the direction of unethical behaviours due to the salience of unethical behaviours on overall perception. The 5-point scale was deliberately chosen to force the respondent to make a choice and avoid the middle ground. The PLIS had high internal consistency with a Cronbach's alpha of greater than $.97^{13}$.

\section{ANALYSIS AND RESULTS}

\section{A.Descriptive Statistics and Intercorrelation}

Table 1. Mean, standard deviation, and correlation

\begin{tabular}{lccc}
\hline Variables & Mean & SD & $\begin{array}{c}\text { Ethical } \\
\text { Leadership }\end{array}$ \\
\hline Inspirational motivation & 4.08 & .61 & $.294^{* *}$ \\
Appropriate role model & 3.98 & .56 & $.225^{* *}$ \\
$\begin{array}{l}\text { Fostering acceptance of } \\
\text { group goals }\end{array}$ & 4.27 & .53 & $.354^{* *}$ \\
$\begin{array}{l}\text { High performance } \\
\text { expectations }\end{array}$ & 4.02 & .53 & .045 \\
$\begin{array}{l}\text { Intellectual stimulation } \\
\text { Individual consideration }\end{array}$ & 4.05 & .48 & $.216^{* *}$ \\
Contingent reward & 4.01 & .47 & $.180^{* *}$ \\
\hline
\end{tabular}

Note: ** Correlation is significant at the 0.01 level (2-tailed).

Table 1 displays the variables Mean, standard 


\section{The Influence of Transformational Leadership on Perceived Ethical Leadership}

Deviation and Correlation. Mean value of inspirational motivation was 4.08. Mean value indicates that respondents of the organisation were inspirationally motivated. Similarly, the mean values of other constructs of transformation leadership were high that shows the positive trend of respondents towards appropriate role model; fostering acceptance of group goals; high performance expectations; intellectual stimulation; individual consideration and contingent reward.

The correlation results indicated that all constructs of the transformational leadership except high performance expectations had positive and significant correlation with ethical leadership.

\section{B. Structural Model Analysis}

SEM using AMOS version 21 was applied to test the hypotheses of this study. The result indicated that the overall structural model of relationship between transformational leadership style and ethical leadership have a good model fit. The structural model analysis indicated that the normed chi-square of structural model was 1.690 that is less than 3 . NFI, TLI and CFA of the structural model were $0.836,0.920$ and 0.925 respectively that are considered satisfactory. RMSEA of the model was 0.043 .

Table 2. The Path Analysis

\begin{tabular}{lcc}
\hline Path & Beta & Result \\
\hline $\begin{array}{c}\text { Individual consideration } \rightarrow \\
\text { Perceived ethical leadership }\end{array}$ & 0.082 & Rejected \\
$\begin{array}{c}\text { Inspirational motivation } \rightarrow \\
\text { Perceived ethical leadership }\end{array}$ & $0.140^{*}$ & Supported \\
$\begin{array}{c}\text { Intellectual stimulation } \rightarrow \\
\quad \text { Perceived ethical leadership }\end{array}$ & -0.105 & Rejected \\
$\begin{array}{l}\text { Fostering acceptance of group } \\
\text { goals } \rightarrow \text { Perceived ethical }\end{array}$ & $0.332^{* *}$ & Supported \\
$\quad$ leadership \\
$\begin{array}{c}\text { High performance expectations } \rightarrow \\
\quad \text { Perceived ethical leadership }\end{array}$ & $-0.177^{*}$ & Contradicted \\
$\begin{array}{c}\text { Appropriate role model } \rightarrow \\
\quad \text { Perceived ethical leadership }\end{array}$ & 0.114 & Rejected \\
$\begin{array}{c}\text { Contingent reward } \rightarrow \text { Perceived } \\
\text { ethical leadership }\end{array}$ & 0.022 & Rejected \\
\hline
\end{tabular}

Table 2 shows the results of hypotheses testing. The first construct named as individual consideration had insignificant positive effect on perceived ethical leadership $(\beta=0.082)$, thus hypothesis $\mathrm{H} 1 \mathrm{a}$ is rejected. Inspirational motivation was hypothesised to have positive significant effect on perceived ethical leadership. Results proved this proposition with positive and significant relationship $(\beta=0.140)$, thus accepted the H1b. Intellectual stimulation was also expected to have positive significant effect on perceived ethical leadership but the results rejected the hypothesis H1c $(\beta=$ -0.105). Fostering acceptance of group goals had positive and significant effect on perceived ethical leadership with standardised estimate of 0.332 so H1d is accepted. Negative but significant effect of high performance expectations was found on perceived ethical leadership with $\beta=-0.177$, thus contradicted with H1e. This is an interesting finding within the police department of Malaysia as it was hypothesised that this relationship must be positively significant. Effect of appropriate role model and contingent reward was positive but insignificant on perceived ethical leadership with standardised regression weights of 0.114 and 0.022 respectively. Therefore, H1f and $\mathrm{H} 1 \mathrm{~g}$ were rejected.

\section{DISCUSSION AND CONCLUSION}

Social learning theory posited that for leaders to be seen as ethical leaders by their followers, they must be attractive and credible role models ${ }^{7}$. Social learning theory is based on the idea that individuals learn by paying attention to, and emulating the attitudes, values and behaviours of, attractive and credible models ${ }^{2}$. Most individuals look outside themselves to other individuals for ethical guidance. Ethical leaders are deemed as likely source of guidance because of their attractiveness and credibility as role models and these traits would draw attention to their model behaviour. Power and status are two characteristics of such model that enhance their attractiveness, thus making it more likely that followers will pay attention to ethical leaders' model behaviour. 'that ethical leadership was associated to consideration behaviour, trustworthiness, faith in the leader, interactional equality, and mingled charismatic leadership (as measured by the idealised influence dimension of transformational leadership). ${ }^{1}$ also established the effect of transformational leadership on ethical behaviour. ${ }^{25}$ found that transformational leadership dimensions of articulate vision, individualised support, appropriate role model, and foster acceptance of group goals are significantly related to ethics at workplace. Therefore, this study hypothesised that the seven dimensions of transformational leadership to have positive influences on perceived ethical leadership. However, this study found that only three dimensions of transformational leadership, namely inspirational motivation, fostering acceptance of group goals, and high performance expectation to have effects on perceived ethical leadership. The relationship of other four dimensions of transformational leadership on perceived ethical leadership could not be established.

These three dimensions of inspirational motivation, fostering acceptance, and high performance expectation are significantly related to the perceived ethical leadership of the police institution by way of the clear vision set by the Malaysian police itself. The study was conducted during the period of the Police Integrity Plan 2010/2015 that clearly outlined their ethical goals and proper conducts as expected by the top police leadership. Apart from the usual crime control and service delivery targets, the value of integrity and ethical conducts were spelt out as key performance indicators of the RMP 5-year Strategic Plan. It would be natural then to assume that the police officers and staff would be inspired by the compelling vision of integrity as articulated by their Inspector-General of Police during the annual Police Day celebrations.

Since the Integrity Plan emphasises the need for all police officers and staff to be ethical, such an expectation would bind them to own up to their organisational goal as a group, rather than simply being ethical individually. These transformational leaders who expect their subordinates to perform dutifully would also be able to transform their respective groups under their command to be a more ethical group in carrying out their duties as required.

Being transformational and ethical leaders co-exist together in this instance because the Police Integrity Plan depicts an ethical leader to be one who understands the police organisational vision, accepts it and performs his or her roles accordingly as expected. Similarly from the eyes of the subordinates, they would perceive their leaders to be 
ethical once these police leaders could lead them as a group to perform in line with the organisational goal as per expected and accepted by all. This contextual justification of transformational leadership dimensions and perceived ethical leadership of the police force were evidenced by the results of the study.

The other explanation is the locus of reference of the transformational leadership dimensions that were significantly accepted. Inspirational motivation, fostering acceptance of group goals and high performance expectation are inherent traits of transformational leadership that could be construed as referring to the leaders' own mirror imagery of leadership. They shape the ethical principles to be such a leader. All these three factors point to the need for them to internalising the core ethical values in forming out their leadership styles. In contrast, the transformational leadership dimensions of contingent reward, appropriate role model, intellectual stimulation and individual consideration; that were rejected; point to refer towards the followers rather than the leaders. They would only be apparent when leaders and followers interact.

In conclusion, this study provides evidence related to the effect of transformational leadership on perceived ethical leaders by the police, specifically in Malaysian context.

\section{REFERENCES}

1. Balasubramaniam, P., \& Krishnan, V. R. (2012). Impact of gender and transformational leadership on ethical behaviors. Great Lakes Herald, 6(1), 45-60.

2. Bandura, A. (1977). Social learning theory. New Jersey: Prentice Hall.

3. Bass, B. M. (1985). Leadership and performance beyond expectations. New York: The Free Press.

4. Bass, B. M. (1997). Does the transactional/transformational leadership paradigm transcend organizational and national boundaries? American Psychologist, 52(2), 130-139.

5. Bass, B. M., \& Steidlmeier, P. (1999). Ethics, character, and authentic transformational leadership behaviour. Leadership Quarterly, 10(2), 181-217.

6. Brown, M. E., \& Trevino, L. K. (2006). Ethical leadership: A review and future directions. The Leadership Quarterly, 17(6), 595-616.

7. Brown, M. E., Trevino, L. K., \& Harrison, D. A. (2005). Ethical leadership: A social learning perspective for construct development and testing. Organizational Behavior and Human Decision Processes, 97(2), 117-134.

8. Burns, J. M. (1978). Leadership. New York: Harper and Row.

9. Callow, N., Smith, M. J., Hardy, L., Arthur, C. A., \& Hardy, J. (2009). Measurement of transformational leadership and its relationship with team cohesion and performance level. Journal of Applied Sport Psychology, 21(4), 395-412.

10. Carter, M. Z., Mossholder, K. W., Feild, H. S., \& Armenakis, A. A (2014). Transformational leadership, interactional justice, and organizational citizenship behavior: The effects of racial and gender dissimilarity between supervisors and subordinates. Group \& Organization Management, 39(6), 691-719.

11. Cascio, W. F. (1995). Whither industrial and organizational psychology in a changing world of work? American Psychologist, 50(11), 928-939.

12. Casey, J., \& Mitchell, M. (2007). Police leadership and management. Sydney: The Federation Press

13. Clarkson, J. A. (2009). Perceptions of leadership and integrity: A correlation of followers' assessments. (Doctoral dissertation), Capella University.

14. Craig, S. B., \& Gustafson, S. B. (1998). Perceived leader integrity scale: An instrument for assessing employee perceptions of leader integrity. Leadership Quarterly, 9(2), 127-145.

15. Dukerich, J. M., Nichols, M. L., Elm, D. R., \& Vollrath, D. A. (1990). Moral reasoning in groups: Leaders make a difference. Human Relation, 43(5), 473-493.

16. Graham, J. W. (1995). Leadership, moral development, and citizenship behavior. Business Ethics Quarterly, 5(1), 43-54.

17. Howell, J. M., \& Avolio, B. J. (1992). The ethics of charismatic leadership: Submission or liberation? The Executive, 6(2), 43-54.
18. Klockars, C. B., Ivokovic, S. K., Harver, W. E., \& Haberfeld, M. R. (2004). The contours of police integrity. Thousand Oaks, CA: SAGE Publications.

19. Meaklim, T., \& Sims, J. (2011). Leading Powerful Partnerships - a new model of public sector leadership development. The International Journal of Leadership in Public Services, 7(1), 21-31.

20. Pearson-Goff, M., \& Herrington, V. (2013). Police Leaders and Leadership Development: a Systematic Literature Review. Australian Institute of Police Management Research Focus(1), 3 .

21. Porter, L. E. (2005). Policing the police service: Theoretical and practical contributions of psychologists to understanding and preventing corruption. In L. J. Alison (Ed.), The Forensic Psychologist's Casebook: Psychological Profiling and Criminal Investigation (pp. 143-169). Cullompton, Devon: Willan.

22. Porter, L. E., Webb, S., Prenzler, T., \& Gill, M. (2015). The Role of Leadership in Promoting Ethical Police Behaviour. Coventry: College of Policing

23. Report of the Royal Commission to Enhance the Operation and Management of the Royal Malaysia Police. (2005). Kuala Lumpur: Percetakan Nasional Malaysia Berhad.

24. Simola, S., Barling, J., \& Turner, N. (2012). Transformational leadership and leaders' mode of care reasoning. Journal of Business Ethics, 108(2), 229-237.

25. Singh, K. (2011). Developing ethics at the workplace through transformational leadership: a study of business organizations in India. Journal of Knowledge Globalization, 4(2).

26. Transparency International. (2013). Global corruption barometer 2013. Retrieved from http://www.transparency.org/gcb2013/results

27. Trevino, L. K., Brown, M. E., \& Hartman, L. P. (2003). A qualitative investigation of perceived executive ethical leadership: Perceptions from inside and outside the executive suite. Human Relation, 56(1), $5-37$

28. Wang, G., Oh, I., Courtright, S. H., \& Colbert, A. (2011) Transformational leadership and performance across criteria and levels: A meta-analytic review of 25 years of research. Group \& Organization Management, 36(2), 223-270.

29. Report of the Royal Commission to Enhance the Operation and Management of the Royal Malaysia Police. (2005). Kuala Lumpur: Percetakan Nasional Malaysia Berhad.

\section{AUTHORS PROFILE}

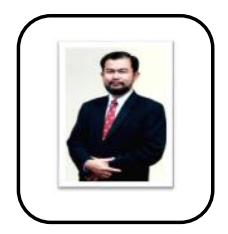

Mohd. Nizam Mohd. Ali is a Senior Director of Institut Integriti Malaysia. He obtained his PhD in Management from Universiti Teknologi Malaysia in 2016. His research interests are related business ethics and integrity and good governance. Currently, he is actively involved in research and consultation related to ethics and integrity.

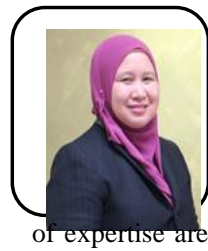

Siti Aisyah Binti Panatik Abdul Rahman is Associate Professor of Psychology at School of HRD and Psychology (SHARPS), Universiti Teknologi Malaysia. She graduated with a PhD in Psychology from University of Waikato, New Zealand in 2010. Currently, she is involved actively in research and consultation. Her areas to Work design, Work-Life Balance, Occupationa Well-being, Work-Related Attitudes and Behaviors, Positive Psychology, and Corporate Integrity. She authored a book titled "The Impact of Integrity in Malaysia". She served as the editor of several books, including Psychological Issues at Workplace, Individual Personality at Workplace, Issues in Academia and Psychological Well-being at Workplace.

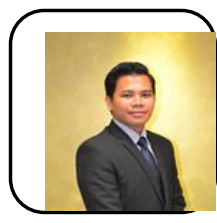

Mohammad Saipol Mohd Sukor is a Senior Lecturer at School of HRD and Psychology (SHARPS), Universiti Teknologi Malaysia. He obtained his PhD in Management from Universiti Teknologi Malaysia in 2017. His research interests are work stress, occupational well-being and humor at workplace.

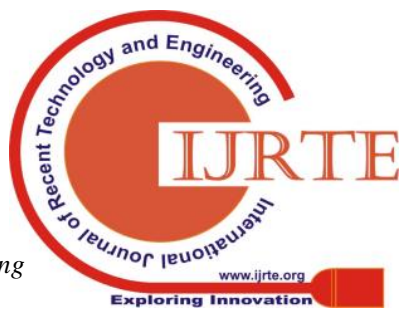


The Influence of Transformational Leadership on Perceived Ethical Leadership

Azizah Rajab is Associate Professor at the Language Academy, Universiti Teknologi Malaysia, Johor Bahru Campus. She obtained her PhD in Applied Linguistics from Leicester University, UK in 1996. She is with UTM for more than 31 years and currently active in research related to Second Language, Educational

Psychology, Higher Education and Social Science. 